\title{
Interspecific variation in juvenile snapper otolith chemical signatures in the northern Gulf of Mexico
}

\author{
William F. Patterson III ${ }^{1, *}$, Beverly K. Barnett ${ }^{2}$, Michelle Zapp Sluis ${ }^{3}$, \\ James H. Cowan Jr. ${ }^{4}$, Alan M. Shiller ${ }^{5}$

\begin{abstract}
${ }^{1}$ University of South Alabama and Dauphin Island Sea Lab, 101 Bienville Blvd, Dauphin Island, Alabama 36528, USA Panama City Beach, Florida 32408, USA

${ }^{3}$ Harte Research Institute for Gulf of Mexico Studies, Texas A\&M University - Corpus Christi, 6300 Ocean Drive, Corpus Christi, Texas 78412, USA

${ }^{4}$ Department of Oceanography and Coastal Sciences, Louisiana State University, Baton Rouge, Louisiana 70803, USA

${ }^{5}$ University of Southern Mississippi, Department of Marine Science, 1020 Balch Blvd., Stennis Space Center,
\end{abstract} \\ ${ }^{2}$ National Marine Fisheries Service, Southeast Fisheries Science Center, Panama City Laboratory, 3500 Delwood Beach Road, \\ Mississippi 39529, USA
}

\begin{abstract}
The objective of this study was to evaluate whether age-0 lane snapper Lutjanus synagris otolith chemical signatures could serve as accurate proxies for those of its congener, red snapper L. campechanus, among northern Gulf of Mexico (GOM) nursery regions. Red (n = 90) and lane $(n=53)$ snappers were sampled from 3 regions of the northern GOM in fall 2005, and their otolith chemistry was analyzed with sector field-inductively coupled plasma-mass spectrometry (Ba:Ca, Mg:Ca, Mn:Ca, Sr:Ca, Li:Ca) or stable isotope ratio-mass spectrometry $\left(\delta^{13} \mathrm{C}\right.$ and $\delta^{18} \mathrm{O}$ ). Chemical signatures were significantly different among regions (MANOVA, $\mathrm{p}<0.001$ ) and between species (MANOVA, $p=0.029$ ), with the species effect being driven by significant differences in 4 of the 7 constituents analyzed (ANOVA, $p<0.036$ ). The significant region effect persisted (MANOVA, $p<0.001$ ), but the species effect was non-significant (MANOVA, $p=0.964$ ) when constituent values were normalized to species-specific means. Mean regional classification accuracies from linear discriminant functions computed with otolith constituent data were $84 \%$ for lane snapper and $80 \%$ for red snapper whether data were normalized or not. Maximum likelihood models parameterized with normalized lane snapper otolith chemistry data estimated red snapper regional composition reasonably well among mixed-region samples (mean error $=9.7 \%$ among models). Therefore, it appears age-0 lane snapper otolith chemical signatures can serve as accurate proxies for those of red snapper in the northern GOM. These results have broader implications for deriving natural tags based on otolith chemistry for fishes that may have low abundance in parts of their range.
\end{abstract}

KEY WORDS: Otolith chemistry · Snapper · Nursery areas

\section{INTRODUCTION}

The global rise of ecosystem-based management, including coastal zone planning and the creation of marine protected areas, has resulted in an increased demand for understanding the population structure of marine organisms (Hall \& Mainprize

${ }^{*}$ Corresponding author: wpatterson@disl.org
2004, Crowder et al. 2006, Ciannelli et al. 2013). Several approaches have been developed to examine population structure and connectivity among invertebrate and vertebrate marine fauna, including molecular techniques, modeling egg and larval transport, and applying artificial and natural tags to examine population connectivity. In reef fishes, results

(C) The authors 2014. Open Access under Creative Commons by Attribution Licence. Use, distribution and reproduction are unrestricted. Authors and original publication must be credited. 
from recent population genetics studies and oceanographic transport modeling suggest self-recruitment may be more widespread than previously thought (Cowen et al. 2000, Swearer et al. 2002, van der Meer et al. 2012, Ackiss et al. 2013). Furthermore, population connectivity in some species may be driven by post-settlement movement, rather than egg and larval transport (Bolden 2000, Lindberg et al. 2006, Patterson 2007). Unfortunately, artificial tagging is impractical for many reef fishes, and the ability to estimate site fidelity or movement can be limited in tagged fishes due to tag loss, uneven fishing effort, or low reporting rates. Therefore, the need to develop accurate, reliable natural tags is paramount to examine post-settlement movement and population connectivity in reef fishes.

Otolith chemical signatures have been shown to be effective natural tags in fishes, and examining population connectivity and estimating nursery sources with otolith chemical signatures has become widespread in fish ecology (reviewed in Campana \& Thorrold 2001, Elsdon et al. 2008, Chang \& Geffen 2013). Employing otolith chemical signatures has been particularly effective for examining recruitment dynamics and population connectivity in estuarinedependent and diadromous fishes. This is due to typically high variability in water chemistry among estuaries driving differences in otolith chemical signatures, or a significant contrast existing between the water chemistry fish experience as juveniles versus adults. Among reef fishes, otolith chemical signatures have been demonstrated to distinguish nursery areas or systems for a variety of estuarine-dependent species (Gillanders \& Kingsford 2003, Hanson et al. 2004). However, otolith chemical signatures have also proven effective in distinguishing nursery areas or regions in reef fishes that spend their entire life cycle on the shelf (H. M. Patterson et al. 2005, Ruttenberg et al. 2008). Among those is red snapper Lutjanus campechanus (Patterson et al. 2008, Zapp Sluis et al. 2012), a large (body mass to $25 \mathrm{~kg}$ and total length to $1 \mathrm{~m}$ ) lutjanid that is one of the more ecologically and economically important reef fishes in the northern GOM.

Red snapper is the most targeted reef fish in US waters of the GOM despite being estimated to be severely overfished for over $30 \mathrm{yr}$ (Porch 2007, SEDAR 2013). The stock has begun to recover in recent years, principally due to increasingly restrictive management measures mandated by the re-authorization of the Magnuson-Stevens Fishery Management and Conservation Act, which was passed by the US Congress in 2006. The GOM fishery began along the west Florida shelf in the 1800s (Stearns 1883, Collins 1885), but by the turn of the 19th century the red snapper population was commercially extinct in Florida waters (Porch et al. 2007). A clear sign of stock recovery in recent years has been increasing catch rates and abundance estimates in the eastern GOM (SEDAR 2013). Artificial tagging data indicate some young fish $(<5 \mathrm{yr}$ old $)$ move from the north central GOM to the west Florida shelf post-settlement (Patterson 2007, Addis et al. 2013), but it is unknown what percentage of the growing red snapper population found there is locally produced versus recruits from other regions of the GOM.

Zapp Sluis et al. (2012) examined age-0 red snapper otolith chemical signatures among 6 regions of the GOM, including the west Florida shelf and 2 regions in Mexican waters, in an attempt to develop natural tags to examine sources of recruits to rebuilding red snapper populations in the northern GOM. Despite significant sampling efforts, they collected relatively few juvenile red snapper from the west Florida shelf, and had no samples from that region for 1 of the 3 yr classes they examined. Lane snapper Lutjanus synagris, however, are abundant on the west Florida shelf, thus the question arose as to whether lane snapper otolith chemical signatures could serve as a proxy for those of red snapper, given similarities in ecology, early life history, and GOM habitats between these 2 congeners (Workman et al. 2002, Mikulas \& Rooker 2008, Wells et al. 2008). To test this question, age-0 red and lane snapper juveniles were sampled concurrently among 3 northern GOM regions, and differences in otolith chemical signatures between species were tested. Then, the ability of lane snapper otolith chemical signatures to accurately distinguish mixed-region red snapper samples was examined.

\section{METHODS}

Age-0 red and lane snappers were sampled in October and November 2005 from 3 regions in the northern GOM during the National Oceanic and Atmospheric Administration (NOAA) Fisheries Fall Groundfish Survey (FGS): north central Gulf (NCG), northwest Gulf (NWG), and southwest Gulf (SWG) (Fig. 1). Following Patterson et al. (2008), the boundary between NWG and NCG regions was longitude $89.0^{\circ} \mathrm{W}$, and the boundary between NWG region and SWG regions was $94.5^{\circ} \mathrm{W}$. Fish were placed in plastic bags, frozen onboard the research vessel, and then transferred to the laboratory for processing. Fish 


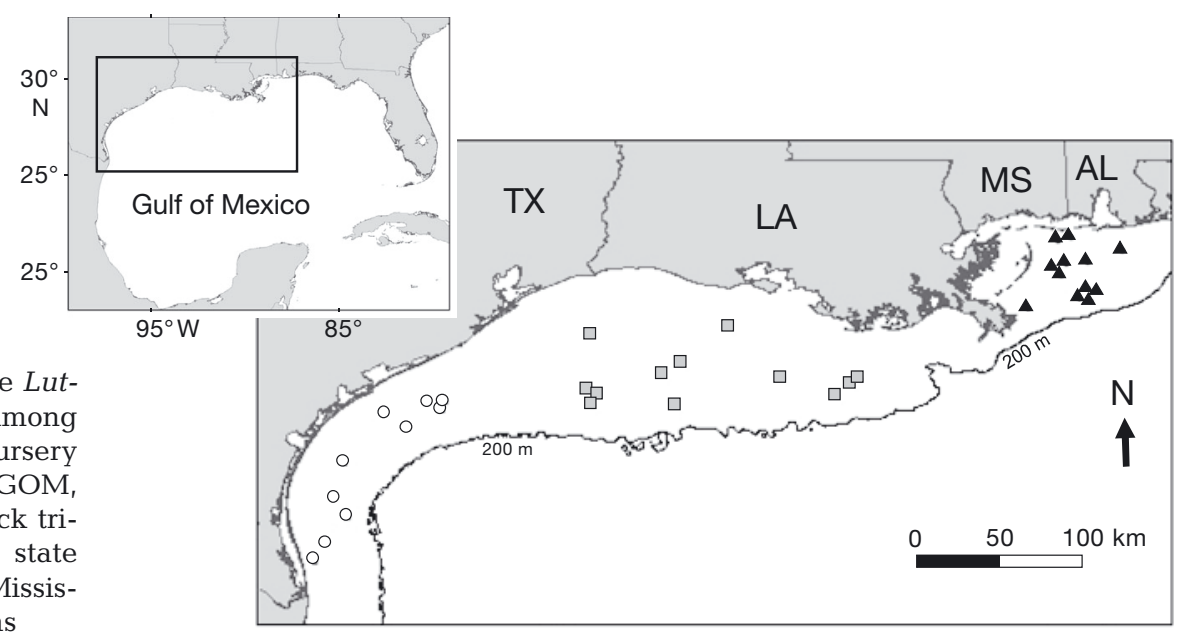

Fig. 1. Sampling locations for juvenile Lutjanus campechanus and L. synagris among northern Gulf of Mexico (GOM) nursery regions. Unfilled circles = southwest GOM gray squares $=$ northwest GOM, black triangles $=$ north central GOM. US state abbreviations: $\mathrm{AL}=$ Alabama, $\mathrm{MS}=$ Mississippi, LA = Louisiana, $\mathrm{TX}=$ Texas

red snapper otoliths (Sturgeon et al. 2005). SRM were thawed, measured to the nearest $\mathrm{mm}$ total length (TL) and wet mass recorded to the nearest $0.01 \mathrm{~g}$. Right and left sagittae were extracted with acidleached glass probes and Teflon forceps and rinsed with ultrapure (18.3 $\left.\mathrm{M} \Omega \mathrm{cm}^{-1}\right)$ water. Each otolith was cleaned with $1 \%$ ultrapure $\mathrm{HNO}_{3}$ for $30 \mathrm{~s}$ to remove any surface tissue, rinsed repeatedly with ultrapure water to remove acid, and then placed under a Class 10 laminar flow hood to air dry for at least $24 \mathrm{~h}$.

Whole otoliths were analyzed for chemical constitutes such that otolith chemical signatures were integrated over the entire nursery period experienced by juveniles prior to sampling. Right otoliths were processed for elemental analysis by dissolving them in $1 \%$ ultrapure $\mathrm{HNO}_{3}$ at a dilution factor of approximately 1000x; exact dilution factors were determined by mass. Aliquots $(5 \mathrm{ml})$ of otolith solutions were analyzed with a ThermoFisher Element 2 sector fieldinductively coupled plasma-mass spectrometer (SFICP-MS) in the Department of Marine Science at the University of Southern Mississippi. Otolith solutions were spiked with indium at a concentration of 2.5 parts per billion (ppb) as an internal standard, and then analyzed for ${ }^{137} \mathrm{Ba}_{1}{ }^{48} \mathrm{Ca}_{1}{ }^{7} \mathrm{Li},{ }^{55} \mathrm{Mn},{ }^{24} \mathrm{Mg}$, and ${ }^{88} \mathrm{Sr}$, with concentrations of individual elements expressed as molar ratios to $\mathrm{Ca}$. All elements were analyzed in medium resolution mode, except for $\mathrm{Ba}, \mathrm{Li}$, and $\mathrm{Mn}$, which were analyzed in low resolution. Blanks of $1 \%$ ultrapure $\mathrm{HNO}_{3}$ were processed through the same stages of preparation as sample solutions. Blanks were analyzed concurrently with sample solutions to estimate instrument limits of detection (LOD), which were estimated as 3 standard deviations of mean blank values. Instrument performance and matrix effects were checked by assaying elemental concentrations of an otolith standard reference material (SRM; FEBS-1) prepared from adult solutions were prepared with the exact protocols as otolith samples.

Left otoliths were processed for stable isotope analysis by pulverizing samples to a fine, homogenized powder with acid-leached glass mortars and pestles and then transferred to microcentrifuge tubes. Subsamples (>1 mg) of pulverized otoliths were analyzed at the Stable Isotope Laboratory in the Department of Geology at the University of California at Davis with a Finnigan MAT 251 isotope ratio mass spectrometer (IR-MS). Instrument calibration was conducted against the International Atomic Energy Agency's carbonate standard, NBS-19. Analytical run accuracies were measured through routine analysis of an in-house check standard which had been stringently calibrated against NBS-19. Results of IR-MS analysis are reported in $\delta$-notation $\left\{\delta X=\left[\left(R_{\text {sample }} / R_{\text {standard }}\right)-1\right] \times\right.$ 1000 , where $X={ }^{13} \mathrm{C}$ or ${ }^{18} \mathrm{O}$ and $\mathrm{R}={ }^{13} \mathrm{C} /{ }^{12} \mathrm{C}$ or ${ }^{18} \mathrm{O} /$ $\left.{ }^{16} \mathrm{O}\right\}$, and are expressed as per mil (\%o) relative to the international carbonate standard Vienna Peedee Belemnite (V-PDB).

Parametric assumptions of element:Ca and stable isotope data were tested prior to statistical analysis; all statistical tests were conducted with an experimentwise error rate $(\alpha)$ of 0.05 . Normality was tested with Ryan-Joiner tests and homogeneity of variances was tested with $F_{\max }$ tests. Constituents that violated parametric assumptions were either ln-transformed or reciprocal-transformed prior to statistical analysis. Species-specific relationships between TL and element:Ca or stable isotope values were tested with correlation analysis. Differences in otolith chemical signatures were tested with a 2-factor multivariate analysis of variance (MANOVA), with species and region main effects. These effects also were tested with ANOVA for individual constituents (i.e. element:Ca 
or stable isotope ratios) (SAS Institute 2009). Following initial analysis of otolith chemical signatures, data were normalized for each constituent by dividing individual values by the species-specific mean among regions. Species and region effects then were retested with MANOVA and ANOVA as indicated above.

Linear discriminant function (LDF) analysis was conducted with non-normalized and normalized data for both red and lane snappers to evaluate whether juveniles could be distinguished among northern GOM regions with otolith chemical signatures (SAS Institute 2009). Lastly, maximum likelihood stock mixing models were parameterized with normalized lane snapper data to test whether the regional composition of unknown red snapper samples could be estimated accurately based on lane snapper otolith chemical signatures (Millar 1990). Regional composition of unknown red snapper samples included $100 \%$ from a single region $(\mathrm{n}=30), 50 \%$ from 1 region and $25 \%$ randomly selected from each of the other 2 regions $(n=60)$, and $33 \%$ from each region $(n=90)$.

\section{RESULTS}

A total of 143 age- 0 red $(n=90)$ and lane $(n=53)$ snapper juveniles was sampled among northern GOM regions (Fig. 1, Table 1). Samples were drawn from a broad geographic range within each region, although FGS stations produced fewer lane than red snapper samples. The range in TL was similar among regions within each species, but mean TL was between 17 and $32 \mathrm{~mm}$ greater for lane snapper than for red snapper sampled in the same region (Table 1). There was no significant difference in red snapper TL among regions (ANOVA, $\mathrm{p}=0.589$ ), but TL was significantly different among regions for lane snapper (ANOVA, $\mathrm{p}=0.006$ ).

Table 1. Descriptive statistics of Lutjanus campechanus and L. synagris sampled from the 3 regions in the northern Gulf of Mexico (Gulf) in fall 2005. NCG = north central Gulf, NWG = northwest Gulf, SWG = southwest Gulf

\begin{tabular}{|lcccc|}
\hline Species & Region & $\mathrm{n}$ & Stations & $\begin{array}{c}\text { Mean } \pm \text { SE } \\
\text { total length }(\mathrm{mm})\end{array}$ \\
\hline L. campechanus & $\mathrm{NCG}$ & 30 & 12 & $110.0 \pm 3.2$ \\
& $\mathrm{NWG}$ & 30 & 13 & $112.5 \pm 3.2$ \\
& SWG & 30 & 10 & $110.3 \pm 3.2$ \\
L. synagris & NCG & 16 & 7 & $127.4 \pm 4.4$ \\
& NWG & 18 & 9 & $144.8 \pm 4.2$ \\
& SWG & 19 & 9 & $137.1 \pm 4.1$ \\
\hline
\end{tabular}

Elemental concentrations were at least 2 orders of magnitude above LODs for each element analyzed with SF-ICP-MS, and analysis of the FEBS-1 SRM yielded concentration estimates within $5 \%$ of certified values. Values for $\delta^{13} \mathrm{C}$ and $\delta^{18} \mathrm{O}$ in the carbonate standard were within $1 \%$ of certified values during IR-MS analysis. All element:Ca ratios were ln-transformed and both stable isotope ratios were reciprocaltransformed to meet parametric assumptions.

The only constituent that was significantly correlated to TL for either species was Mn:Ca ( $p<0.04, \mathrm{r}=$ -0.362 for lane snapper and $r=-0.328$ for red snapper). However, the correlations were weak and removing the effect of TL from ln-transformed Mn:Ca had no effect on subsequent statistical analyses.

Otolith chemical signatures were significantly different among regions and between species (MANOVA, $\mathrm{p}<0.001$; Table 2, Fig. 2). The region effect was significant for all constituents except Ba:Ca and $\mathrm{Sr}: \mathrm{Ca}$ (ANOVA, $p \geq 0.053$ ), and the species effect was significant for all constituents except $\mathrm{Mg}: \mathrm{Ca}, \mathrm{Mn}: \mathrm{Ca}$, and $\delta^{13} \mathrm{C}$ (ANOVA, $\mathrm{p} \geq 0.057$; Table 2, Fig. 2). Despite the significant species effect for most constituents, trends in mean constituent values were similar between species. The significant region effect persisted (MANOVA, p < 0.001; Table 3, Fig. 3) but the species effect was non-significant (MANOVA, $p=0.964$ ) when constituent values were normalized to speciesspecific means. The removal of the species effect is also reflected in results from ANOVAs run on individual constituents (Table 3 ).

Mean region-specific jackknifed classification accuracies from LDFs computed with otolith constituent data were $84 \%$ for lane snapper and $80 \%$ for red snapper (Fig. 4). Identical results were produced with normalized data, thus indicating the variancecovariance structure of otolith chemical signatures was unaffected by normalizing the data. Maximum likelihood models parameterized with normalized lane snapper otolith chemistry data estimated red snapper regional composition reasonably well among mixed-region samples (Table 4). The mean error was $9.7 \%$ among models; however, results were least accurate for models in which red snapper samples were derived $100 \%$ from a single region.

\section{DISCUSSION}

Several criteria must be met for nursery-specific otolith chemical signatures of one fish species to be effectively employed as proxies for another species. Chemical signatures must be sufficiently different 
Table 2. Results of MANOVA and ANOVA models computed to test for differences in otolith chemical signatures between age-0 Lutjanus campechanus and L. synagris among Gulf of Mexico regions. The statistic computed in the MANOVA model was Pillai's Trace and mean square error (from Type III sum of squares) in ANOVA models

\begin{tabular}{|c|c|c|c|c|}
\hline Model & $\begin{array}{l}\text { Statistic } \\
\text { value }\end{array}$ & $F$-value & df & prob. $>F$ \\
\hline \multicolumn{5}{|l|}{ MANOVA } \\
\hline Region & 0.804 & 12.78 & 14,264 & $<0.001$ \\
\hline Species & 0.490 & 17.99 & 7,131 & $<0.001$ \\
\hline Region $\times$ Species & 0.283 & 3.11 & 14,264 & $<0.001$ \\
\hline \multicolumn{5}{|l|}{ Ba:Ca ANOVA } \\
\hline Region & 0.003 & 0.03 & 2,142 & 0.971 \\
\hline Species & 0.379 & 4.49 & 1,142 & 0.036 \\
\hline Region $\times$ Species & 0.137 & 1.63 & 2,142 & 0.200 \\
\hline \multicolumn{5}{|l|}{ Li:Ca ANOVA } \\
\hline Region & 0.214 & 18.81 & 2,142 & $<0.001$ \\
\hline Species & 0.067 & 5.90 & 1,142 & 0.016 \\
\hline Region $\times$ Species & 0.038 & 3.30 & 2,142 & 0.040 \\
\hline \multicolumn{5}{|l|}{ Mg:Ca ANOVA } \\
\hline Region & 0.363 & 21.50 & 2,142 & $<0.001$ \\
\hline Species & 0.062 & 3.69 & 1,142 & 0.057 \\
\hline Region $\times$ Species & 0.009 & 0.51 & 2,142 & 0.600 \\
\hline \multicolumn{5}{|l|}{ Mn:Ca ANOVA } \\
\hline Region & 0.913 & 9.45 & 2,142 & $<0.001$ \\
\hline Species & 0.093 & 0.97 & 1,142 & 0.328 \\
\hline Region $\times$ Species & 0.209 & 2.16 & 2,142 & 0.119 \\
\hline \multicolumn{5}{|l|}{ Sr:Ca ANOVA } \\
\hline Region & 0.014 & 3.00 & 2,142 & 0.053 \\
\hline Species & 0.052 & 11.09 & 1,142 & 0.001 \\
\hline Region $\times$ Species & 0.019 & 4.14 & 2,142 & 0.018 \\
\hline \multicolumn{5}{|l|}{$\delta^{13} \mathrm{C}$ ANOVA } \\
\hline Region & 0.026 & 36.63 & 2,142 & $<0.001$ \\
\hline Species & 0.001 & 0.57 & 1,142 & 0.453 \\
\hline Region $\times$ Species & 0.005 & 6.54 & 2,142 & 0.002 \\
\hline \multicolumn{5}{|l|}{$\delta^{18} \mathrm{O}$ ANOVA } \\
\hline Region & 0.115 & 3.62 & 2,142 & 0.030 \\
\hline Species & 2.996 & 77.23 & 1,142 & $<0.001$ \\
\hline Region $\times$ Species & 0.053 & 1.35 & 2,142 & 0.262 \\
\hline
\end{tabular}

among nursery areas or regions for each species, high species-specific classification accuracy from statistical models computed with chemical signatures must exist, and nursery origin of a sample of juveniles from the second species must be accurately estimated based on a rule function derived from signatures of the first species. Based on these criteria, results of the current study suggest that regionspecific otolith chemical signatures of lane snapper can be employed as accurate proxies for those of its congener, red snapper, in the northern GOM.

Otolith chemical signatures clearly were significantly different among regions for both red and lane snapper juveniles (see Patterson et al. 2008 and Zapp Sluis et al. 2012 for interpretation of regional differ-
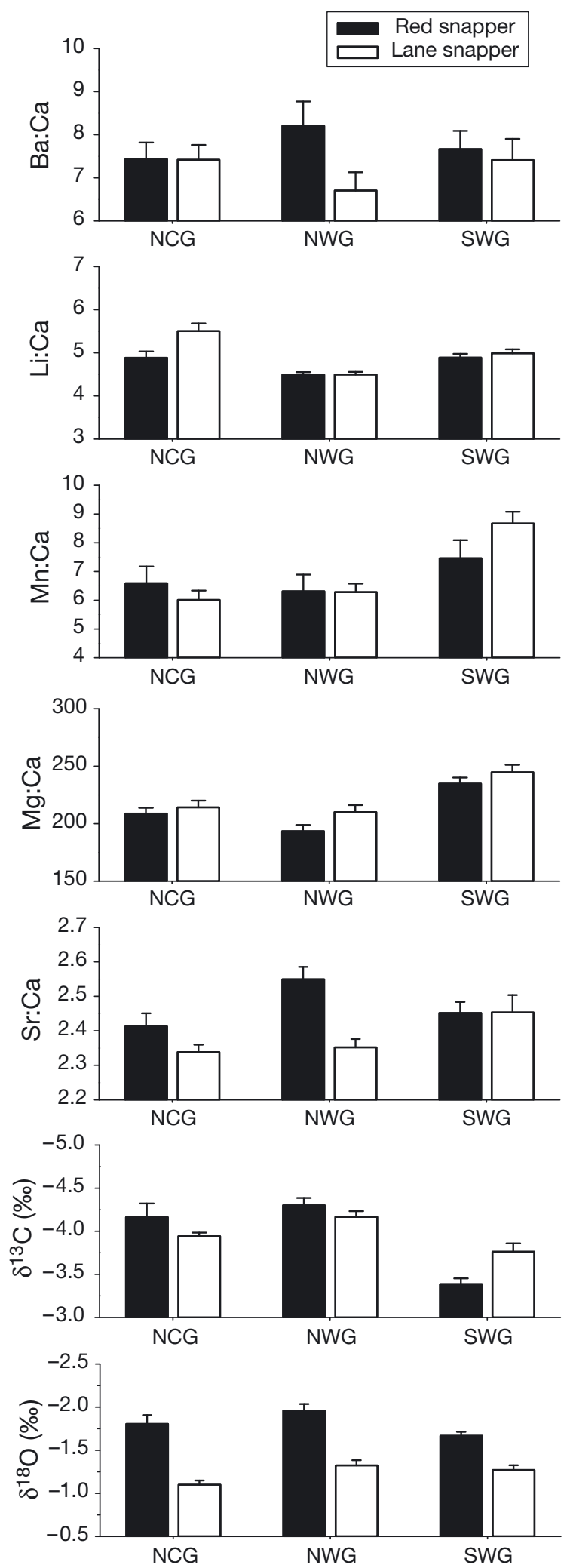

Fig. 2. Mean $(+\mathrm{SE})$ values for otolith element:Ca ratios or carbonate stable isotopes for juvenile Lutjanus campechanus and L. synagris sampled from northern Gulf of Mexico nursery regions. See Table 1 for region abbreviations 
Table 3. Results of MANOVA and ANOVA models computed to test for differences in normalized otolith chemical signatures between age-0 Lutjanus campechanus and $L$. synagris among Gulf of Mexico regions. The statistic computed in the MANOVA model was Pillai's Trace and mean square error (from Type III sum of squares) in ANOVA models

\begin{tabular}{|c|c|c|c|c|}
\hline Model & $\begin{array}{l}\text { Statistic } \\
\text { value }\end{array}$ & $F$-value & df & prob. $>F$ \\
\hline \multicolumn{5}{|l|}{ MANOVA } \\
\hline Region & 0.808 & 12.78 & 14,264 & $<0.001$ \\
\hline Species & 0.014 & 0.27 & 7,131 & 0.964 \\
\hline Region $\times$ Species & 0.285 & 3.14 & 14,264 & $<0.001$ \\
\hline \multicolumn{5}{|l|}{ Ba:Ca ANOVA } \\
\hline Region & 0.003 & 0.03 & 2,142 & 0.971 \\
\hline Species & 0.018 & 0.22 & 1,142 & 0.643 \\
\hline Region $\times$ Species & 0.137 & 1.63 & 2,142 & 0.200 \\
\hline \multicolumn{5}{|l|}{ Li:Ca ANOVA } \\
\hline Region & 0.214 & 18.81 & 2,142 & $<0.001$ \\
\hline Species & 0.001 & 0.12 & 1,142 & 0.730 \\
\hline Region $\times$ Species & 0.038 & 3.30 & 2,142 & 0.040 \\
\hline \multicolumn{5}{|l|}{ Mg:Ca ANOVA } \\
\hline Region & 0.363 & 21.50 & 2,142 & $<0.001$ \\
\hline Species & 0.001 & 0.01 & 1,142 & 0.932 \\
\hline Region $\times$ Species & 0.009 & 0.51 & 2,142 & 0.600 \\
\hline \multicolumn{5}{|l|}{ Mn:Ca ANOVA } \\
\hline Region & 0.913 & 9.45 & 2,142 & $<0.001$ \\
\hline Species & 0.016 & 0.16 & 1,142 & 0.685 \\
\hline Region $\times$ Species & 0.209 & 2.16 & 2,142 & 0.119 \\
\hline \multicolumn{5}{|l|}{ Sr:Ca ANOVA } \\
\hline Region & 0.014 & 3.00 & 2,142 & 0.053 \\
\hline Species & 0.001 & 0.01 & 1,142 & 0.984 \\
\hline Region $\times$ Species & 0.019 & 4.14 & 2,142 & 0.018 \\
\hline \multicolumn{5}{|l|}{$\delta^{13} \mathrm{C}$ ANOVA } \\
\hline Region & 0.398 & 36.42 & 2,142 & $<0.001$ \\
\hline Species & 0.001 & 0.07 & 1,142 & 0.787 \\
\hline Region $\times$ Species & 0.070 & 6.40 & 2,142 & 0.002 \\
\hline \multicolumn{5}{|l|}{$\delta^{18} \mathrm{O}$ ANOVA } \\
\hline Region & 0.232 & 3.62 & 2,142 & 0.030 \\
\hline Species & 0.056 & 0.88 & 1,142 & 0.351 \\
\hline Region $\times$ Species & 0.093 & 1.46 & 2,142 & 0.237 \\
\hline
\end{tabular}

ences). Chemical signatures also were significantly different between species when tested with nonnormalized data, which was driven by significant differences in the individual constituents, $\mathrm{Ba}: \mathrm{Ca}, \mathrm{Li}: \mathrm{Ca}$, $\mathrm{Sr}: \mathrm{Ca}$, and $\delta^{18} \mathrm{O}$. However, patterns among regions were similar between species even for constituents for which the species effect was significant. Normalizing the data to species-specific mean values effectively removed the species effect from MANOVA and ANOVA models while preserving the variance structure of the data with respect to the regional effect, as inferred from nearly identical results for the region effect for the models computed with normalized data. Normalizing the data also had no effect on
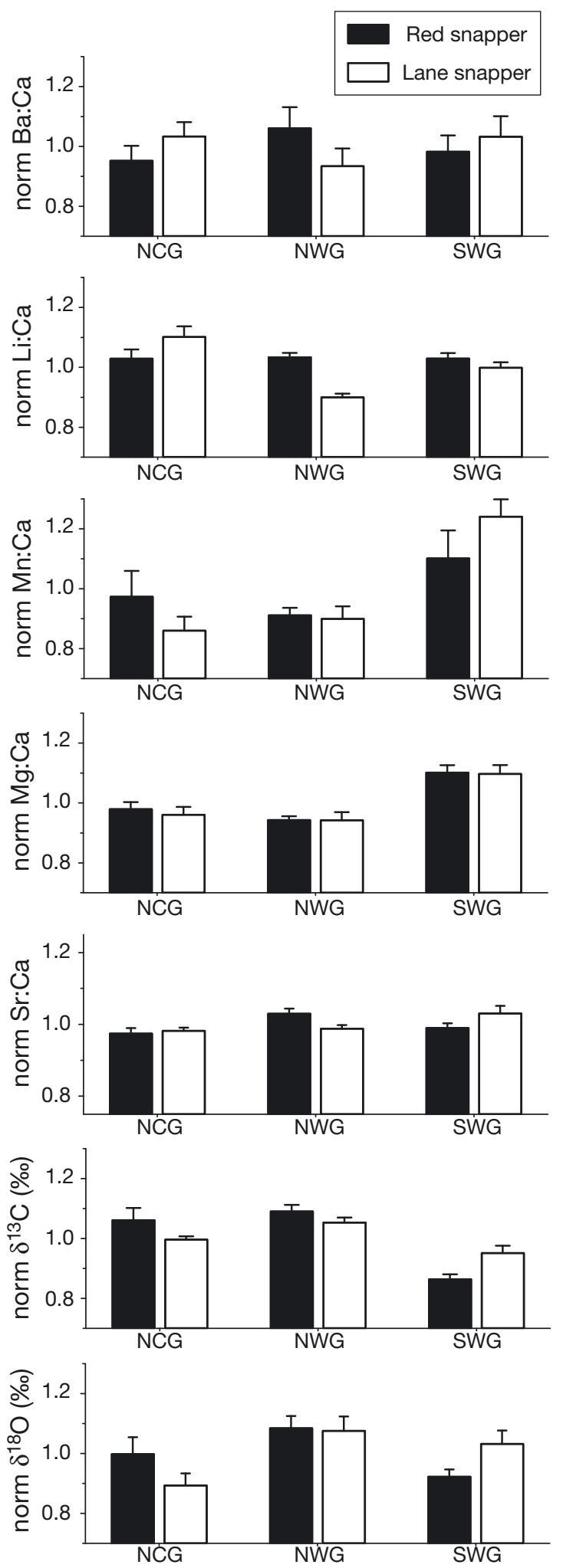

Fig. 3. Normalized mean (+SE) values for otolith element:Ca ratios or carbonate stable isotopes for juvenile Lutjanus campechanus and L. synagris sampled from northern Gulf of Mexico nursery regions. See Table 1 for region abbreviations 


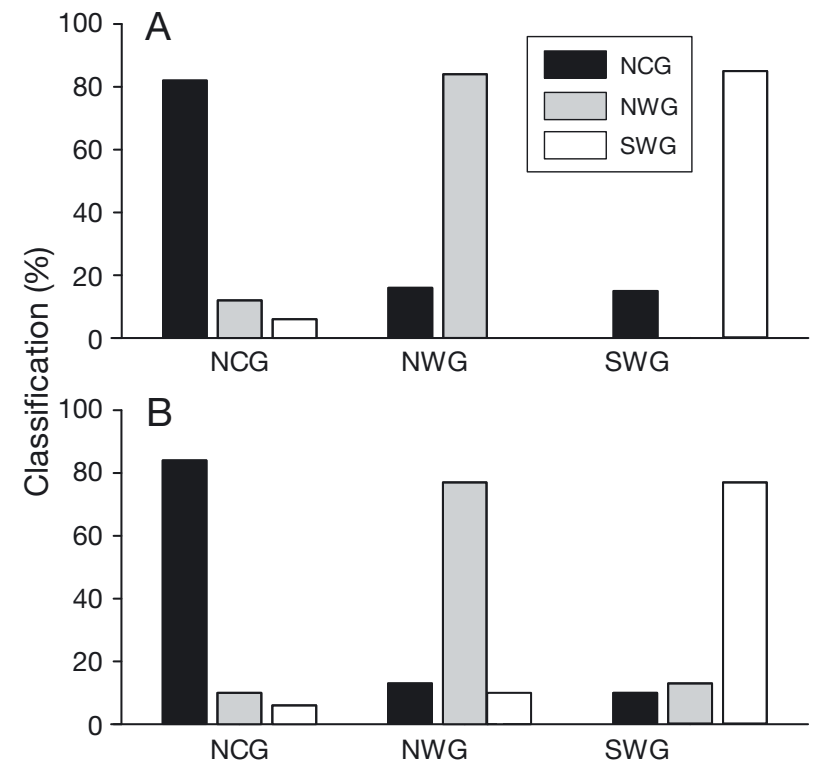

Fig. 4. Jackknifed classification accuracies from linear discriminant function analysis of (A) Lutjanus synagris and (B) L. campechanus samples from northern Gulf of Mexico nursery regions. See Table 1 for region abbreviations

high ( $\geq 80 \%$ ) jackknifed nursery region classification accuracies from LDFs computed for either lane or red snapper. However, the ultimate test of lane snapper otolith chemical signatures serving as proxies is their ability to distinguish red snapper nursery sources, and maximum likelihood models parameterized with normalized lane snapper otolith chemical signatures accurately (mean error $<10 \%$ ) predicted nursery region of mixed-source red snapper samples.

Authors of other studies have reported significant differences in otolith chemical signatures among species sampled from the same nursery habitats or systems (Gillanders \& Kingsford 2003, Hamer \&
Jenkins 2007, Reis-Santos et al. 2008, 2012). Typically, co-located species which are more closely related phylogenetically and ecologically tend to have more similar otolith chemical signatures (reviewed in Chang \& Geffen 2013). For example, Brown (2006) reported otolith elemental composition was similar between juvenile flatfishes English sole Pleuronectes vetulus and speckled sanddab Citharichthys stigmaeus co-located among 3 regions along the coast of California, and that mean regionspecific LDF classification accuracies differed little when species were modeled separately (78 and $79 \%$, respectively) versus jointly $(77 \%)$. Swearer et al. (2003) also reported that otolith signatures more similar among southern California estuaries for fishes that were more closely related phylogenetically and ecologically. Among species they examined, the flatfishes Paralichthys californicus and Hypsopsetta guttulata had otolith chemical signatures more similar to each other than to the other species sampled, as did the gobies Clevelandia ios and Ilypnus gilberti. Furthermore, chemical signatures were more similar between the flatfishes and gobies than between these benthic fishes and the mid-water topsmelt Atherinops affinis. It also should be noted that the flatfishes were juveniles of estuarine-dependent species that eventually emigrate out of estuaries to shelf environments, while the gobies were adults that typically have restricted $\left(10 \mathrm{~s}\right.$ of $\left.\mathrm{m}^{2}\right)$ home ranges (Swearer et al. 2003). Therefore, other factors such as life stage, growth rate, and feeding ecology also may have affected observed interspecific differences.

The 2 species examined in the current study belong to the subfamily Lutjaninae within the family Lutjanidae. Not only are they closely related phylogenetically (Gold et al. 2011), they also have very

Table 4. Maximum likelihood regional composition estimates of mixed-region age-0 Lutjanus campechanus samples from the northern Gulf of Mexico. Models were parameterized with region-specific otolith chemical signatures of L. synagris. Model percentage indicates the regional composition of $L$. campechanus mixed-region samples. See Table 1 for region abbreviations

\begin{tabular}{|c|c|c|c|c|c|c|c|c|}
\hline \multicolumn{3}{|c|}{ Model percentage -} & \multicolumn{3}{|c|}{ Estimated percentage -} & \multicolumn{3}{|c|}{ _ Difference } \\
\hline $\mathrm{NCG}$ & NWG & SWG & $\mathrm{NCG}$ & NWG & SWG & $\mathrm{NCG}$ & NWG & SWG \\
\hline 100 & 0 & 0 & 72.5 & 9.1 & 18.4 & -27.5 & 9.1 & 18.4 \\
\hline 0 & 100 & 0 & 0.0 & 77.1 & 22.9 & 0.0 & -22.9 & 22.9 \\
\hline 0 & 0 & 100 & 11.3 & 18.3 & 70.4 & 11.3 & 18.3 & -29.6 \\
\hline 33 & 33 & 33 & 26.3 & 36.1 & 37.6 & -6.7 & 3.1 & 4.6 \\
\hline 50 & 50 & 0 & 33.8 & 44.9 & 21.2 & -16.2 & -5.1 & 21.2 \\
\hline 50 & 0 & 50 & 41.9 & 13.7 & 44.4 & -8.1 & 13.7 & -5.6 \\
\hline 0 & 50 & 50 & 3.2 & 48.5 & 47.3 & 3.2 & -1.5 & -2.7 \\
\hline 50 & 25 & 25 & 41.7 & 31.8 & 26.7 & -8.3 & 6.8 & 1.7 \\
\hline 25 & 50 & 25 & 22.0 & 50.9 & 28.8 & -3.0 & 0.9 & 3.8 \\
\hline 25 & 25 & 50 & 34.1 & 24.7 & 45.9 & 9.1 & -0.3 & -4.1 \\
\hline
\end{tabular}


similar ecologies in the northern GOM, especially during early life. Both species spawn during spring and summer months and juveniles settle out in a variety of shelf habitats, although they are most concentrated in shell rubble habitat (Workman et al. 2002, Mikulas \& Rooker 2008, Wells et al. 2008). Juveniles typically spend at least their first year of life associated with these habitats prior to recruiting to reefs later in their second year of life, and their feeding ecologies overlap as well, with juvenile diets consisting principally of zooplankton, benthic invertebrates, squids, and transitioning to greater piscivory with ontogeny (Franks \& VanderKooy 2000, W. F. Patterson et al. 2005, McCawley \& Cowan 2007, Mikulas \& Rooker 2008). Therefore, few species are as similar phylogenetically and ecologically in the northern GOM as red and lane snappers, factors that Swearer et al. (2003) and Chang \& Geffen (2013) concluded had great influence on the similarity of otolith chemical signatures between species.

A variety of factors, such as salinity, temperature, growth, or food, can affect the incorporation of constituents examined in red and lane snapper otoliths (Elsdon et al. 2008, Chang \& Geffen 2013). For example, $\mathrm{Sr}$ and Ba concentrations in otoliths of several species, including gray snapper Lutjanus griseus, have been shown to reflect ambient concentrations in water, although their incorporation into otoliths may be affected to a lesser extent by water temperature and growth rate (Bath et al. 2000, Elsdon \& Gillanders 2002, Martin \& Wuenschel 2006, Walther \& Thorrold 2006). Red and lane snappers have overlapping spawning seasons in the northern GOM, thus juveniles likely were present on the shelf and exposed to ambient conditions over the same time period. The large size for lane snapper juveniles may result from faster growth, as their mean growth rate tends to be on the upper end of the range observed for red snapper juveniles (Mikulas \& Rooker 2008, Wells et al. 2008).

Differential growth rate could have implications for $\delta^{18} \mathrm{C}$ but it is unlikely to cause differences observed in $\delta^{18} \mathrm{O}$ (Thorrold et al. 1997, Høie et al. 2003). Regional patterns in $\delta^{18} \mathrm{O}$ were similar between snapper species, with fish sampled in the NWG having the lowest and fish in the SWG having the highest $\delta^{18} \mathrm{O}$ values, which likely resulted from lower $\delta^{18} \mathrm{O}$ in Mississippi River water relative to GOM water and relatively little freshwater input onto the shelf from Texas rivers (Bowen \& Wilkinson 2002, Dutton et al. 2005, Wagner \& Slowey 2011). The inter-specific difference in $\delta^{18} \mathrm{O}$, however, is more difficult to explain. Within a species, $\delta^{18} \mathrm{O}$ has been shown to be incorporated into otoliths in close equilibrium with ambient water, with fractionation driven by water temperature and independent of growth or metabolic effects (Thorrold et al. 1997, Høie et al. 2003). However, differences in $\delta^{18} \mathrm{O}$ fractionation have been reported among species such that a universal equation relating water temperature to $\delta^{18} \mathrm{O}$ in otoliths has been elusive (Patterson et al. 1993, Thorrold et al. 1997, Høie et al. 2004). Differences in $\delta^{18} \mathrm{O}$ observed between red and lane snappers ranged from 0.40 to $0.71 \%$ among GOM regions. This is within the range in otolith $\delta^{18} \mathrm{O}$ reported among species for a given water temperature (Høie et al. 2004), although it is unclear if one should expect such a difference in $\delta^{18} \mathrm{O}$ for 2 species as closely related as red and lane snappers without the fish having experienced different water temperatures.

The last otolith constituent for which there was a significant difference between snapper species was Li:Ca. Lithium is typically 2 orders of magnitude more concentrated in oceanic than riverine waters, and that is true of the Mississippi River, the predominant freshwater source in the northern GOM (Huh et al. 1998). The volume of Mississippi River water on the shelf in the NWG likely explains the lower otolith $\mathrm{Li}: \mathrm{Ca}$ in that region. However, the incorporation of $\mathrm{Li}$ into otoliths is poorly understood so no definitive inference can be drawn either with respect to $\mathrm{Li}: \mathrm{Ca}$ among regions or between snapper species. Furthermore, it should be noted that Li:Ca values were similar for red and lane snapper juveniles in the NWG and SWG, but the significant species effect was driven by Li:Ca being approximately $10 \%$ higher for red snapper in the NCG.

Overall, results from this study suggest that juvenile lane snapper otolith chemical signatures can serve as effective proxies for those of red snapper among northern GOM nursery regions. Significant differences were apparent between species as well as among regions when non-normalized data were analyzed, but normalizing the data effectively removed the species effect. Therefore, if juvenile red snapper samples were unavailable or lacking from GOM regions then lane snapper otolith chemical signatures could be utilized to produce proxies for red snapper. Such an approach could be employed on the west Florida shelf where juvenile red snapper currently are rarely encountered. This would be critical for parameterizing maximum likelihood or Bayesian assignment models computed to estimate source regions for adults because without west Florida juvenile signatures or proxies, models could never predict local self-recruitment. Beyond red snapper, our results may have implications for other 
closely related species as well, especially if one species is relatively rare in some part of its range, but the proxy approach should be validated by controlled experiments to examine what factors affect constituents of interest in otoliths of these species.

Acknowledgements. The authors thank National Marine Fisheries Service personnel for aiding sample collection during the 2005 NOAA Fisheries Fall Groundfish Survey in the northern GOM. They also thank Mr. David Winter for running SIR-MS analyses for otolith $\delta 13 \mathrm{C}$ and $\delta 18 \mathrm{O}$. Lastly, Bill Kline aided in figure creation. The funding source for this work was NOAA MaRFIN grant NA05NMF4331072 to W.F.P. and J.H.C.

\section{LITERATURE CITED}

Ackiss AS, Pardede S, Crandall ED, Carmen M and others (2013) Pronounced genetic structure in a highly mobile coral reef fish, Caesio cuning, in the Coral Triangle. Mar Ecol Prog Ser 480:185-197

Addis DT, Patterson WF III, Dance MA (2013) Implications of reef fish movement from unreported artificial reef sites in the northern Gulf of Mexico. Fish Res 147:349-358

Bath GE, Thorrold SR, Jones CM, Campana SE, McLaren JW, Lam JWH (2000) Strontium and barium uptake in aragonitic otoliths of marine fish. Geochim Cosmochim Acta 64:1705-1714

Bolden SK (2000) Long-distance movement of a Nassau grouper (Epinephelus striatus) to a spawning aggregation in the central Bahamas. Fish Bull 98:642-645

> Bowen GJ, Wilkinson B (2002) Spatial distribution of $\delta^{18} \mathrm{O}$ in meteoric precipitation. Geology 30:315-318

> Brown JA (2006) Classification of juvenile flatfishes to estuarine and coastal habitats based on the elemental composition of otoliths. Estuar Coast Shelf Sci 66:594-611

> Campana SE, Thorrold SR (2001) Otoliths, increments, and elements: keys to a comprehensive understanding of fish populations? Can J Fish Aquat Sci 58:30-38

Chang MY, Geffen AJ (2013) Taxonomic and geographic influences on fish otolith microchemistry. Fish Fish 14: 458-492

Ciannelli L, Fisher JAD, Skern-Mauritzen M, Hunsicker ME, Hidalgo M, Frank KT, Bailey KM (2013) Theory, consequences and evidence of eroding population spatial structure in harvested marine fishes: a review. Mar Ecol Prog Ser 480:227-243

Collins JW (1885) The red snapper grounds in the Gulf of Mexico. Bull US Fish Comm 5:145-146

> Cowen RK, Kamazima M, Lwiza M, Sponaugle S, Paris CB, Olson DB (2000) Connectivity of marine populations: Open or closed? Science 287:857-859

Crowder LB, Osherenko G, Young OR, Airame S and others (2006) Resolving mismatches in US ocean governance. Science 313:617-618

> Dutton A, Wilkinson BH, Welker JM, Bowen GJ, Lohmann $\mathrm{KC}$ (2005) Spatial distribution and seasonal variation in ${ }^{18} \mathrm{O} /{ }^{16} \mathrm{O}$ of modern precipitation and river water across the conterminous USA. Hydrol Processes 19:4121-4126

Elsdon TS, Gillanders BM (2002) Interactive effects of temperature and salinity on otolith chemistry: challenges for determining environmental histories of fish. Can J Fish Aquat Sci 59:1796-1808

Elsdon TS, Wells BK, Campana SE, Gillander BM and others (2008) Otolith chemistry to describe movements and lifehistory parameters of fishes: hypotheses, assumptions, limitations and inferences. Oceanogr Mar Biol Annu Rev 46:297-330

Franks JS, VanderKooy KE (2000) Feeding habits of juvenile lane snapper Lutjanus synagris from Mississippi coastal waters, with comments on the diet of gray snapper Lutjanus griseus. Gulf Caribb Res 12:11-17

Gillanders BM, Kingsford MJ (2003) Spatial variation in elemental composition of otoliths of three species of fish (family Sparidae). Estuar Coast Shelf Sci 57:1049-1064

Gold JR, Voelker G, Renshaw MA (2011) Phylogenetic relationships of tropical western Atlantic snappers in the subfamily Lutjaninae (Lutjanidae: Perciformes) inferred from mitochondrial DNA sequences. Biol J Linn Soc 102: 915-929

> Hall SJ, Mainprize B (2004) Towards ecosystem-based fisheries management. Fish Fish 5:1-20

> Hamer PA, Jenkins GP (2007) Comparison of spatial variation in otolith chemistry of two fish species and relationships with water chemistry and otolith growth. J Fish Biol 71:1035-1055

Hanson PJ, Koenig CC, Zdanowicz VS (2004) Elemental composition of otoliths used to trace estuarine habitats of juvenile gag Mycteroperca microlepis along the west coast of Florida. Mar Ecol Prog Ser 267:253-265

Høie H, Folkvord A, Otterlei E (2003) Effect of somatic and otolith growth rate on stable isotopic composition of early juvenile cod (Gadus morhua L.) otoliths. J Exp Mar Biol Ecol 289:41-58

Høie H, Folkvord A, Otterlei E (2004) Temperature-dependent fractionation of stable oxygen isotopes in otoliths of juvenile cod (Gadus morhua L.). ICES J Mar Sci 61:243-251

> Huh Y, Chan LH, Zhang L, Edmond JM (1998) Lithium and its isotopes in major world rivers: implications for weathering and the oceanic budget. Geochim Cosmochim Acta 62:2039-2051

Lindberg WJ, Frazer TK, Portier KM, Vose F and others (2006) Density-dependent habitat selection and performance by a large mobile reef fish. Ecol Appl 16:731-746

Martin GB, Wuenschel MJ (2006) Effect of temperature and salinity on otolith elemental incorporation in juvenile gray snapper Lutjanus griseus. Mar Ecol Prog Ser 324: 229-239

McCawley JR, Cowan JH Jr (2007) Seasonal and size specific diet and prey demand of red snapper on Alabama artificial reefs. Am Fish Soc Symp 60:71-96

> Mikulas JJ, Rooker JR (2008) Habitat use, growth, and mortality of post-settlement lane snapper (Lutjanus synagris) on natural banks in the northwestern Gulf of Mexico. Fish Res 93:77-84

> Millar RB (1990) Comparison of methods for estimation of mixed stock fishery composition. Can J Fish Aquat Sci 47:2235-2241

Patterson WF III (2007) A review of Gulf of Mexico red snapper movement studies: implications for population structure. Am Fish Soc Symp 60:221-236

Patterson WP, Smith GR, Lohmann KC (1993) Continental paleothermometry and seasonality using the isotopic composition of aragonitic otoliths of freshwater fishes. Geophys Monogr 78:191-202

Patterson HM, Kingsford MJ, McCulloch MT (2005) Resolu- 
tion of the early life history of a reef fish using otolith chemistry. Coral Reefs 24:222-229

Patterson WF III, Wilson CA, Bentley SJ, Cowan JH, Henwood T, Allen YC, Dufrene TA (2005) Delineating juvenile red snapper habitat on the northern Gulf of Mexico continental shelf. Am Fish Soc Symp 41:277-288

Patterson WF III, Cowan JH Jr, Wilson CA, Shipp RL (2008) Temporal and spatial variability in juvenile Gulf of Mexico red snapper otolith elemental signatures in the northern Gulf of Mexico. Trans Am Fish Soc 137:521-532

Porch CE (2007) An assessment of the red snapper fishery in the US Gulf of Mexico using a spatially-explicit agestructured model. Am Fish Soc Symp 60:325-351

Porch CE, Turner SC, Schirripa MJ (2007) Reconstructing the commercial landings of red snapper in the Gulf of Mexico from 1872 to 1963. Am Fish Soc Symp 60:309-324

Reis-Santos P, Vasconcelos RP, Ruano M, Latkoczy C, Gunther D, Costa MJ, Cabral HN (2008) Interspecific variations of otolith chemistry in estuarine fish nurseries. J Fish Biol 72:2595-2614

Reis-Santos P, Gillanders BM, Tanner SE, Vasconcelos RP, Elsdon TS, Cabral HN (2012) Temporal variability in estuarine fish otolith elemental fingerprints: implications for connectivity assessments. Estuar Coast Shelf Sci 112: 216-224

Ruttenberg BI, Hamilton SL, Warner RR (2008) Spatial and temporal variation in the natal otolith chemistry of a Hawaiian reef fish: prospects for measuring population connectivity. Can J Fish Aquat Sci 65:1181-1192

SAS Institute (2009) SAS/STAT 9.2 user's guide, 2nd edn. SAS Institute, Cary, NC

SEDAR (2013) SEDAR 31: Gulf of Mexico red snapper stock assessment report. Southeast Data, Assessment, and Review, North Charleston, SC

Stearns S (1883) Fluctuations of the fisheries of the US Gulf of Mexico and the proposed investigation of them. Bull

Editorial responsibility: Christine Paetzold,

Oldendorf/Luhe, Germany
US Fish Comm 3:467-468

> Sturgeon RE, Willie SN, Yang L, Greenberg R and others (2005) Certification of a fish otolith reference material in support of quality assurance for trace element analysis. J Anal At Spectrom 20:1067-1071

Swearer SE, Shima JS, Hellberg ME, Thorrold SR and others (2002) Evidence of self-recruitment in demersal marine populations. Bull Mar Sci 70:251-271

> Swearer SE, Forrester GE, Steele MA, Brooks AJ, Lea DW (2003) Spatio-temporal and interspecific variation in otolith trace-elemental fingerprints in a temperate estuarine fish assemblage. Estuar Coast Shelf Sci 56:1111-1123

> Thorrold SR, Campana SE, Jones CM, Swart PK (1997) Factors determining $\delta^{13} \mathrm{C}$ and $\delta^{18} \mathrm{O}$ fractionation in aragonitic otoliths of marine fish. Geochim Cosmochim Acta 61: 2909-2919

> van der Meer MH, Hobbs JPA, Jones GP, van Herwerden L (2012) Genetic connectivity among and self-replenishment within island populations of a restricted range subtropical reef fish. PLoS ONE 7:e49660

Wagner AJ, Slowey NC (2011) Oxygen isotopes in seawater from the Texas-Louisiana shelf. Bull Mar Sci 87:1-12

> Walther BD, Thorrold SR (2006) Water, not food, contributes the majority of strontium and barium deposited in the otoliths of a marine fish. Mar Ecol Prog Ser 311:125-130

Wells RJD, Cowan JH Jr, Patterson WF III, Walters CJ (2008) Trawling effects and habitat selection on life history parameters of Gulf of Mexico red snapper. Can J Fish Aquat Sci 65:2399-2411

> Workman I, Shah A, Foster D, Hataway B (2002) Habitat preferences and site fidelity of juvenile red snapper (Lutjanus campechanus). ICES J Mar Sci 59:S43-S50

Zapp Sluis M, Barnett BK, Patterson WF III, Cowan JH Jr, Shiller AM (2012) Discrimination of juvenile red snapper otolith chemical signatures from Gulf of Mexico nursery regions. Mar Coast Fish 4:587-598

Submitted: September 6, 2013; Accepted: April 10, 2014

Proofs received from author(s): May 7, 2014 